\title{
Consumption of benthic fauna by carnivorous birds in the Wadden Sea
}

\author{
G. Scheiffarth ${ }^{1,2} \&$ G. Nehls ${ }^{1}$ \\ ${ }^{1}$ Forschungs- und Technologiezentrum Westküste der Universität Kiel; Hafentörn, \\ D-25761 Büsum, Germany

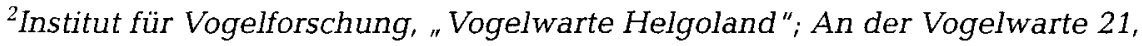 \\ D-26386 Wilhelmshaven, Germany*
}

\begin{abstract}
Consumption by carnivorous birds was estimated for the Sylt-Rømø tidal inlet in the northern part of the Wadden Sea, as well as the subarea Königshafen, a small, tidal bay. The bird community of the Sylt-Rømø Wadden Sea was dominated by Dunlin ( $35 \%$ of all birds counted), Eider $(9 \%)$, Oystercatcher $(8 \%)$, Knot $(8 \%)$, and Shelduck $(7 \%)$. The community in the Königshafen was dominated by Eider $(20 \%)$, Knot $(17 \%)$, Bar-tailed Godwit $(17 \%)$, Dunlin $(13 \%)$, and Oystercatcher $(8 \%)$. Annual consumption was estimated at $3.4 \mathrm{~g} \mathrm{AFDW} \cdot \mathrm{m}^{-2} \cdot$ year ${ }^{-1}$ for the entire SyltRømø Wadden Sea and $19.2 \mathrm{~g} \mathrm{AFDW} \cdot \mathrm{m}^{-2} \cdot$ year $^{-1}$ for the Königshafen. Restricting the calculations to the intertidal area resulted in a consumption of $8.7 \mathrm{~g} \mathrm{AFDW} \cdot \mathrm{m}^{-2} \cdot$ year ${ }^{-1}$ for the Sylt-Rømø Wadden Sea and $17.6 \mathrm{~g} \mathrm{AFDW} \cdot \mathrm{m}^{-2} \cdot$ year $^{-1}$ for the Königshafen. In the two areas, consumption was dominated by the Eider with $37 \%$ and $60 \%$ of the total consumption, respectively. In comparison to the western parts of the Wadden Sea the seasonal pattern of consumption as well as species composition differed, most probably as an effect of different climatic conditions, whereas annual consumption on intertidal flats seems to be in the same order of magnitude. On average, $15-25 \%$ of the mean annual macrozoobenthic biomass seems to be taken by carnivorous birds in the Wadden Sea, which is in the same order of magnitude as in other northern temperate estuarine areas.
\end{abstract}

\section{INTRODUCTION}

The Wadden Sea, a large intertidal area $\left(8000 \mathrm{~km}^{2}\right)$ stretching along the southeastern shore of the North Sea, is of particular importance for migratory birds, which use this area as a stop-over site on their annual migrations between southern wintering and northern breeding areas. About 10-12 million birds spend at least a part of their annual life cycle in this area (Meltofte et al., 1994). Birds are the most prominent members of intertidal ecosystems, often roaming around in spectacular flocks of many thousands. Although the efficiency of energy transfer to birds in intertidal systems is high in comparison to terrestrial ecosystems (Baird \& Milne, 1981; Baird et al., 1985; Krebs, 1985), their role in intertidal ecosystems, if measured as their contribution to energy or carbon flow, is generally considered to be of minor importance, since their consumption only affects a small fraction of primary production and detritus import (Kuipers et al., 1981; Baird et al.,

- Address for correspondence

(c) Biologische Anstalt Helgoland, Hamburg 
1991; Baird \& Ulanowicz, 1993; Meire et al., 1994). This reflects partly the high trophic level of birds and the low production efficiency of animals (Humphreys, 1979; Banse, 1995). However, large differences between areas in the densities of birds and the utilization of benthic communities (Zwarts, 1988; Wolff, 1991; Hockey et al., 1992) indicate that structural differences in these areas affect avian predation pressure. Several mechanisms mitigating avian predation pressure have been proposed: (a) the degree of seasonal synchronisation between production and predation by birds: birds wintering in northern temperate areas use these places at times when annual production is lowest, whereas birds wintering south of the equator meet the annual production peak (Evans, 1979; Hockey et al., 1992); (b) high interannual fluctuations of the benthic macrofauna biomass in northern areas lead to low average consumption (Nehls, 1989; Wolff, 1991); (c) the harvestable fraction of benthic communities, as determined by the quality and the availability of benthic invertebrates to birds, differs seasonally and regionally with low availability and quality in temperate regions in winter (Beukema et al., 1993; Zwarts \& Wanink, 1993); (d) the size of tidal areas, with higher densities of birds in smaller areas (Prater, 1981; Hockey et al., 1992). The first three of the four mechanisms mentioned are caused by the climatic conditions as determined by the geographical positions of the intertidal areas. The geographical position further influences the suitability for birds, as the climatic conditions influence their daily food requirements (Castro et al., 1992; Wiersma \& Piersma, 1994). The consequences of these climatic influences are that the densities of most migratory shorebirds and the total consumption by birds are much higher in southern areas (Zwarts, 1988; Hockey et al., 1992).

The consumption by birds in the Wadden Sea has been mainly investigated in the westernmost parts of the area, where birds consume $5 \mathrm{~g} \mathrm{AFDW} \cdot \mathrm{m}^{-2} \cdot$ year ${ }^{-1}$, which are 10-20\% of the annual macrozoobenthic production (Smit, 1980; Wolff, 1991). Since the entire Wadden Sea spans a region of $2.5^{\circ}$ latitude and $4^{\circ}$ longitude, the climatic conditions at the western end are milder than at its northern end (Eisma, 1980) and bird densities apparently respond to these differences. The densities of wintering waders and hence their consumption was estimated to be eight to ten times higher in the western Dutch Wadden Sea than in the northern Danish Wadden Sea (Zwarts, 1988). We investigated bird populations in a tidal inlet in the northern part of the Wadden Sea and calculated their annual consumption. The aim of the study was to analyse whether consumption by birds is actually lower in this part of the Wadden Sea, or whether differences in species composition and seasonal pattern of consumption result in an equal amount of annual consumption. By comparing a relatively large intertidal area with a small bay we further investigated the impact of area size on bird densities and consumption.

\section{MATERIAL AND METHODS}

\section{Study area}

This study was carried out in the Sylt-Rømø Wadden Sea, a tidal basin in the northern part of the Wadden Sea in the German-Danish borderland (Fig. 1). The islands of Sylt and Rømø, which protect the area from the North Sea, are connected with the main land by causeways. These borders enclose a clearly defined area, which comprises $137.7 \mathrm{~km}^{2}$ of intertidal flats and $299.9 \mathrm{~km}^{2}$ of subtidal area (Table 1). Sandflats are the most common 
Benthic fauna and carnivorous birds

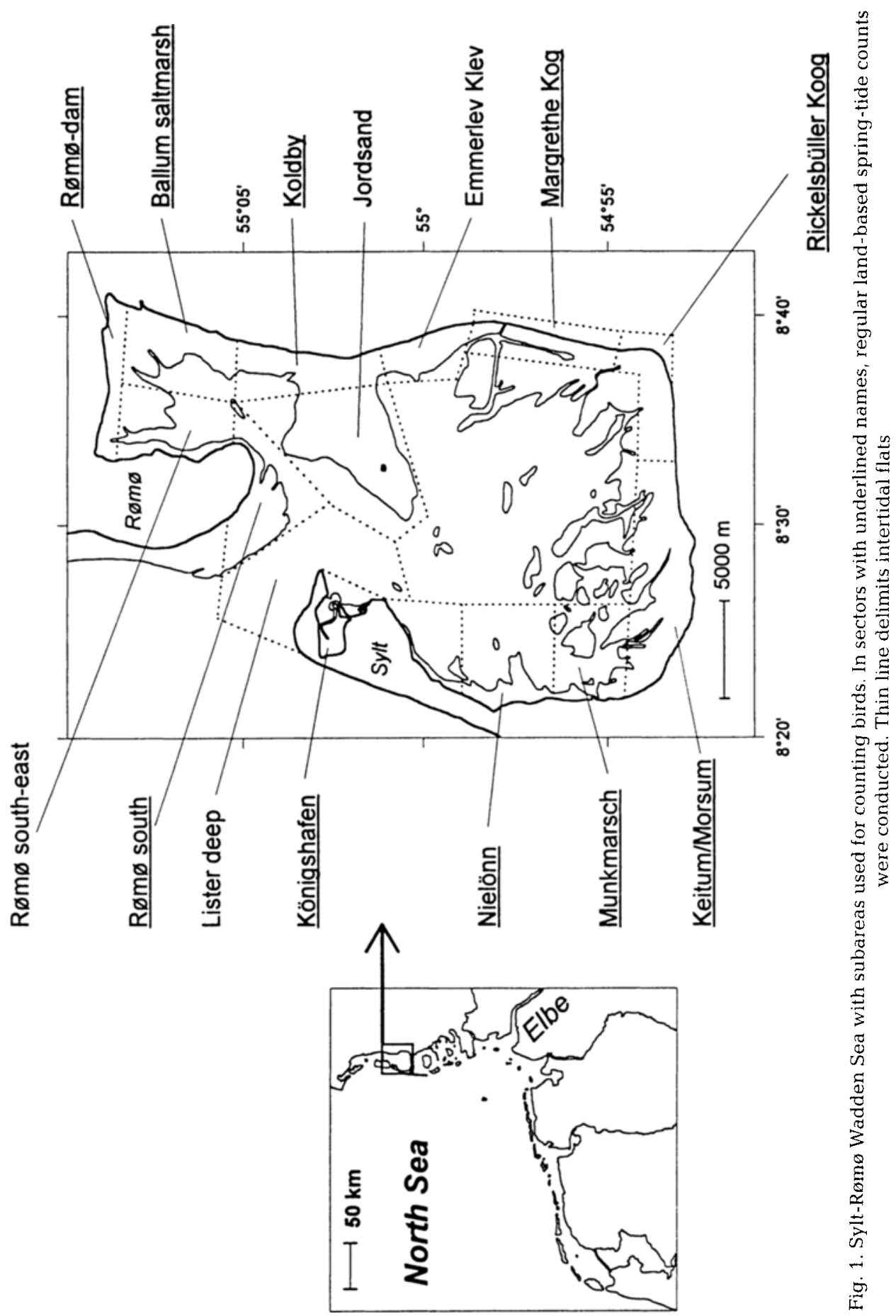


Table 1. Biomass and area composition of the Sylt-Rømø Wadden Sea and the Königshafen

\begin{tabular}{|c|c|c|c|}
\hline & $\begin{array}{l}\text { Sylt-Rømø } \\
\text { Wadden Sea }\end{array}$ & $\begin{array}{l}\text { Königs- } \\
\text { hafen }\end{array}$ & Source \\
\hline Mean intertidal biomass [g AFDW $\cdot \mathrm{m}^{-2}$ ] & 50 & 65 & $\begin{array}{l}\text { Reise et al. (1994); } \\
\text { Lackschewitz (1995) }\end{array}$ \\
\hline $\begin{array}{l}\text { Mean intertidal biomass, without } \\
\text { mollusc shells }\left[\mathrm{g} \mathrm{AFDW} \cdot \mathrm{m}^{-2}\right]\end{array}$ & 40 & 56 & Lackschewitz (1995) \\
\hline Total area (sub- + intertidal) $\left[10^{6} \mathrm{~m}^{2}\right]$ & 437.6 & 5.75 & Backhaus et al. (1995) \\
\hline Intertidal area $\left[10^{6} \mathrm{~m}^{2}\right]$ & 137.7 & 4.32 & Backhaus et al. (1995) \\
\hline$\%$ mudflat & 2.96 & 0.4 & $\begin{array}{l}\text { Bayerl (pers. comm.); } \\
\text { Austen (1994) }\end{array}$ \\
\hline$\%$ sandy mudflat & 21.79 & 10.8 & \\
\hline$\%$ sandflat & 75.25 & 88.8 & \\
\hline$\%$ intertidal covered by mussels & 0.28 & 1 & $\begin{array}{l}\text { Reise et al. (1994); } \\
\text { Lackschewitz (1995) }\end{array}$ \\
\hline
\end{tabular}

type of tidal flats, whereas only a small proportion of the area is covered by mudflats, mainly near the two dams.

The results of the investigation on the whole Sylt-Rømø Wadden Sea are compared with those covering the subarea Königshafen. The latter is a shallow tidal bay at the northern end of Sylt with $4.32 \mathrm{~km}^{2}$ of intertidal and $1.43 \mathrm{~km}^{2}$ of subtidal area. Intertidal sediments consist predominantly of coarse sand, blown in by the wind from nearby dunes, which makes this bay different from other sheltered bays in the Wadden Sea (Austen, 1994). Additionally, a relatively high proportion of the area is covered by mussel-beds (Mytilus edulis) (Reise et al., 1994), concentrated at the mouth of the bay near the low-water line (for a further description, see Reise, 1985). The Königshafen is relatively isolated within the Sylt-Rømø Wadden Sea with the next high-tide roosts for birds 8-9 $\mathrm{km}$ away and the next feeding areas at a distance of $6-7 \mathrm{~km}$.

\section{Bird counts}

Birds were counted in 10 subareas (Fig. 1, underlined areas) during high-tide at each spring-tide (approx. every 15 days) between 1989 and 1995 from dikes, dams or dunes, with the help of telescopes (for a description of the spring-tide counts, see Rösner \& Prokosch, 1992). Breeding and non-breeding birds were not differentiated. On average, in 3.4 years (SD: 1.3, range: $0-6) 5.2$ counts (SD: 2.7, range: $0-14$ ) per month and subarea were conducted. Additionally, aerial surveys were conducted by the Danish National Environmental Research Institute with 37 counts in the northern and eastern parts of the investigation area (Lister Deep - Rickelsbüller Koog) and 8 counts in the western part of the area (Königshafen - Keitum/Morsum; for method, see Pihl \& Frikke, 1992). In the analysis of the aerial counts the results from the subareas Margrethe Kog and Rickelsbüller Koog were excluded, since there were major differences between the latter and simulta- 
neous ground surveys. Usually, the aerial estimates in these areas, which were difficult to scan, were below the estimates of the ground surveys. Redshank, Curlew, Ringed Plover, and Turnstone were excluded from the analysis of all aerial surveys because of major disagreements with ground surveys, which were thought to be more accurate in these species.

For Eiders, special aerial surveys were conducted. Since 1988, 65 surveys were analysed (for a description of the methods, see Nehls, 1991). Ground surveys were only used for the Königshafen, which is the only subarea where Eider numbers can be realistically obtained by land-based counts.

As birds are highly mobile animals, the two dams north and south of the investigation area are no real borders restricting the movements of the birds. This can be a problem when relating bird numbers to a distinct area. Certainly, there is an exchange in birds with adjacent areas, but it was neglected here, as immigration and emigration were supposed to cancel each other out. The problem may become more difficult when relating high-tide counts from the Königshafen to its intertidal area. At least for gulls (Dernedde, 1993), Bar-tailed Godwit and Eider, low-tide counts gave equal numbers for most of the counts. Nevertheless, there may be a slight overestimation of the density estimates for some species based on high-tide counts.

\section{Analysis of the counts}

Despite the integration of the bird counts in an international monitoring project (see Rösner et al., 1994), there were only very few simultaneous counts covering all subareas. To calculate the mean bird numbers for the whole Sylt-Rømø Wadden Sea, each subarea and species had to be treated separately. For each month in each year an average was calculated. Thereafter, the mean for each month across all years was calculated. This method of calculation stresses more the variation between years as if only the mean of all counts per month had been calculated. For June, the missing values for five subareas were interpolated. To obtain the bird numbers for the whole Sylt-Rømø Wadden Sea, the monthly means of each subarea were added up.

\section{Calculation of consumption}

To convert bird numbers into consumption, several assumptions have to be made. We followed the approach of Meire et al. (1994), with few alterations.

The basic formula for conversion is as follows:

$$
\mathrm{C}=\mathrm{D} \cdot 3 \cdot \mathrm{BMR} \cdot(1 / \mathrm{Q}) / \mathrm{E}
$$

where: $C=$ monthly consumption for each species [ $g$ AFDW] (ash free dry weight per month)

$\mathrm{D}=$ number of bird-days per month

$\mathrm{BMR}=$ basal metabolic rate, estimated by using weight dependent equations:

BMR $[W]=5.06 \cdot \mathrm{W}^{0.729}$ for waders (Kersten \& Piersma, 1987)

BMR $[W]=4.8 \cdot W^{0.672}$ for Anseriformes (Brunckhorst \& Hüppop, pers. comm.)

$\mathrm{BMR}[\mathrm{W}]=3.56 \cdot \mathrm{W}^{0.734}$ for all other species (Aschoff \& Pohl, 1970) 
$\mathrm{W}[\mathrm{kg}]=$ weight of the target species; for each month the actual weight was used.

Weights were obtained from literature with data which were recorded as close to the investigation area as possible. This resulted in the following ranking of sources: 1. Prokosch (1988), 2. Smit \& Wolff (1980), 3. Cramp \& Simmons (1983). $\mathrm{BMR}$ values were transformed into $\mathrm{KJ} /$ day

$\mathrm{Q}=$ assimilation efficiency $(80 \%$; mean value of different sources; Kersten \& Piersma, 1987; Castro et al., 1989; Zwarts \& Blomert, 1990)

$\mathrm{E}=22 \mathrm{KJ} / \mathrm{g} \mathrm{AFDW}$; mean energy content of marine benthic animals in the Wadden Sea (Zwarts \& Wanink, 1993)

Daily energy expenditure (DEE) was assumed to be $3 \cdot$ BMR (Kersten \& Piersma, 1987). For Eiders, monthly consumption estimates from a feeding study in the Königshafen were used (Nehls, 1995).

Further assumptions were:

- divers, terns, Cormorant, and Greater Black-backed Gull feed exclusively in the pelagic zone

- Teal, Mallard, Pintail and Golden Plover fulfil $50 \%$ of their energy demands on the zoobenthos of intertidal flats

- diving ducks feed $50 \%$ in the subtidal zone and $50 \%$ in the intertidal zone

- gulls, other than Greater Black-backed Gull, were supposed to rely on food resources from the Wadden Sea. Although these species may also feed on anthropogenic food sources (e.g.: discards, waste), these play only a minor role in the diet in this area (Dernedde, 1993)

\section{Reliability of consumption estimates}

Calculation of consumption is based on allometric equations as well as on many assumptions. However, biomass intake of the main predator, the Eider, is based on observations in the Königshafen. A principal assumption for all other birds was a constant DEE of 3 . BMR throughout the year. Observations of feeding Bar-tailed Godwits in the Königshafen during the migration periods confirmed this value (Scheiffarth, in prep.). The smaller the birds are, the more pronounced a seasonal pattern of DEE becomes (Wiersma et al., 1993), which was not considered in the calculations. We do not think that this has a large effect on the results, since most of the smaller birds leave the area in winter, when DEE is highest. At this time of year, the dominance of the Eider is even more pronounced, so that consumption values appear to be reliable (for further discussion of calculation of consumption, see Meire et al., 1994).

\section{RESULTS}

\section{Species composition}

Regarding carnivorous species only, Dunlin is the most abundant species $(35 \%)$ in the Sylt-Rømø Wadden Sea followed by Eider (9\%), Oystercatcher (8\%), Knot (8\%), and Shelduck $(7 \%)$. These five species comprise $67 \%$ of all carnivorous birds (Fig. 2). Similarly, again five species make up $75 \%$ of all individuals in the Königshafen subarea. 


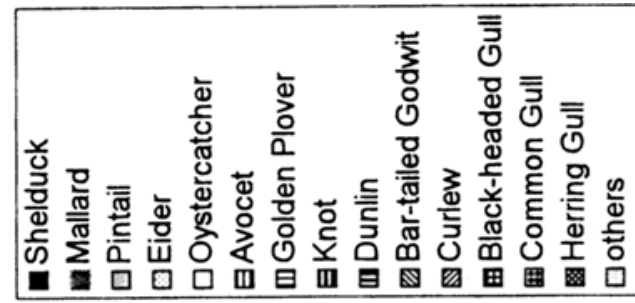

कू
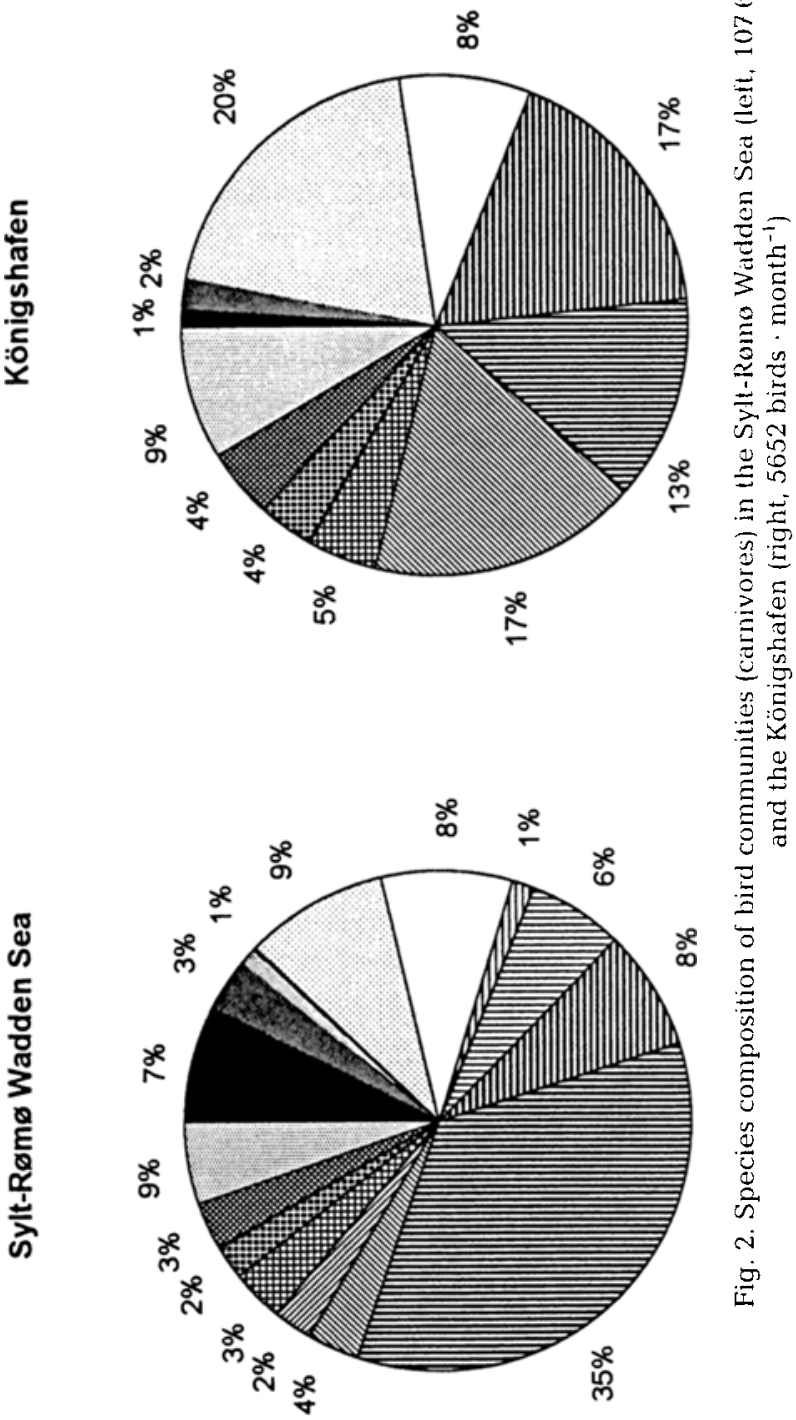
However, in this subarea the Eider is the most abundant species $(20 \%)$ followed by Knot $(17 \%)$, Bar-tailed Godwit (17\%), Dunlin (13\%), and Oystercatcher ( $8 \%)$. The major difference between both areas is the greater dominance of the Eider in the Königshafen, which is an effect of the higher coverage with mussel beds. Furthermore, in the Königshafen the bird community consists of a higher proportion of Bar-tailed Godwits, as well as a reduced proportion of Dunlin and Shelduck, both of which are supposed to be related to the difference in sediment composition between the two areas.

\section{Consumption by birds}

Converting bird numbers into biomass-consumption results in an annual consumption of $1490 \mathrm{t}$ AFDW for the whole Sylt-Rømø Wadden Sea and $111 \mathrm{t}$ AFDW for the Königshafen (Table 2). In the Sylt-Rømø Wadden Sea, the most important predator is the Eider, accounting for $37 \%$ of biomass consumption. Together with Shelduck, Oystercatcher and Dunlin, these four species take $70 \%$ of all biomass consumed by birds in this area. All other bird species play only a minor role (Fig. 3). Consumption is clearly dominated by large birds. Despite the fact that 4 times as many Dunlins as Eiders use the area, the former, small, species consumes only $22 \%$ of the biomass consumed by the Eider. In the Königshafen, the dominance of the Eider in terms of consumption is even more pronounced: almost $2 / 3$ of all biomass consumed by birds is taken by this species. Together with Bar-tailed Godwit, Oystercatcher and Knot, these four species account for $84 \%$ of the consumption by birds.

In relation to the total area, consumption by birds amounts to $3.4 \mathrm{~g} \mathrm{AFDM} \cdot \mathrm{m}^{-2} \cdot$ year $^{-1}$ in the Sylt-Rømø Wadden Sea and $19.2 \mathrm{~g} \mathrm{AFDM} \cdot \mathrm{m}^{-2} \cdot$ year $^{-1}$ in the Königshafen (Table 3). Restricting these calculations to the intertidal area, where most of the species feed, consumption totals $8.7 \mathrm{~g} \mathrm{AFDM} \cdot \mathrm{m}^{-2} \cdot$ year $^{-1}$ for the Sylt-Rømø Wadden Sea and $17.6 \mathrm{~g} \mathrm{AFDM} \cdot \mathrm{m}^{-2}$ year $^{-1}$ for the Königshafen. Even when excluding from these calculations the most dominant predator, the Eider, $80 \%$ of whose food consist of Mussels (Nehls, 1995), the difference between the two areas is still obvious. The subtidal compartment is heavily utilized in the Königshafen and remains almost unused in the Sylt-Rømø Wadden Sea. This difference is related to the much higher share of subtidal area in the Sylt-Rømø Wadden Sea than in the Königshafen, which results in a lower average density of predators in this compartment. Predation in the subtidal compartment is concentrated on Mussel or Cockle beds (Cerastoderma edule), whereas other food resources remain almost unexploited by birds. In both areas, biomass taken from the pelagial is negligible due to the low abundance of birds feeding on fish (ca $1 \%$ of total consumption). Furthermore, consumption in this compartment is almost exclusively restricted to summer and early autumn.

Due to migratory movements of birds, consumption is not equally distributed throughout the year. In the Sylt-Rømø Wadden Sea, consumption reaches a peak in autumn and remains on a high level until January (Fig. 4). This pattern is mostly influenced by the presence of Eiders and other ducks, especially Shelduck. In contrast, waders have the biggest share in consumption during spring.

The same seasonal pattern appears for the Königshafen. Again, this pattern is mostly influenced by the Eider, with an increasing importance of waders in spring. In all, high levels of consumption are reached, when benthic biomass is already decreasing or on a 


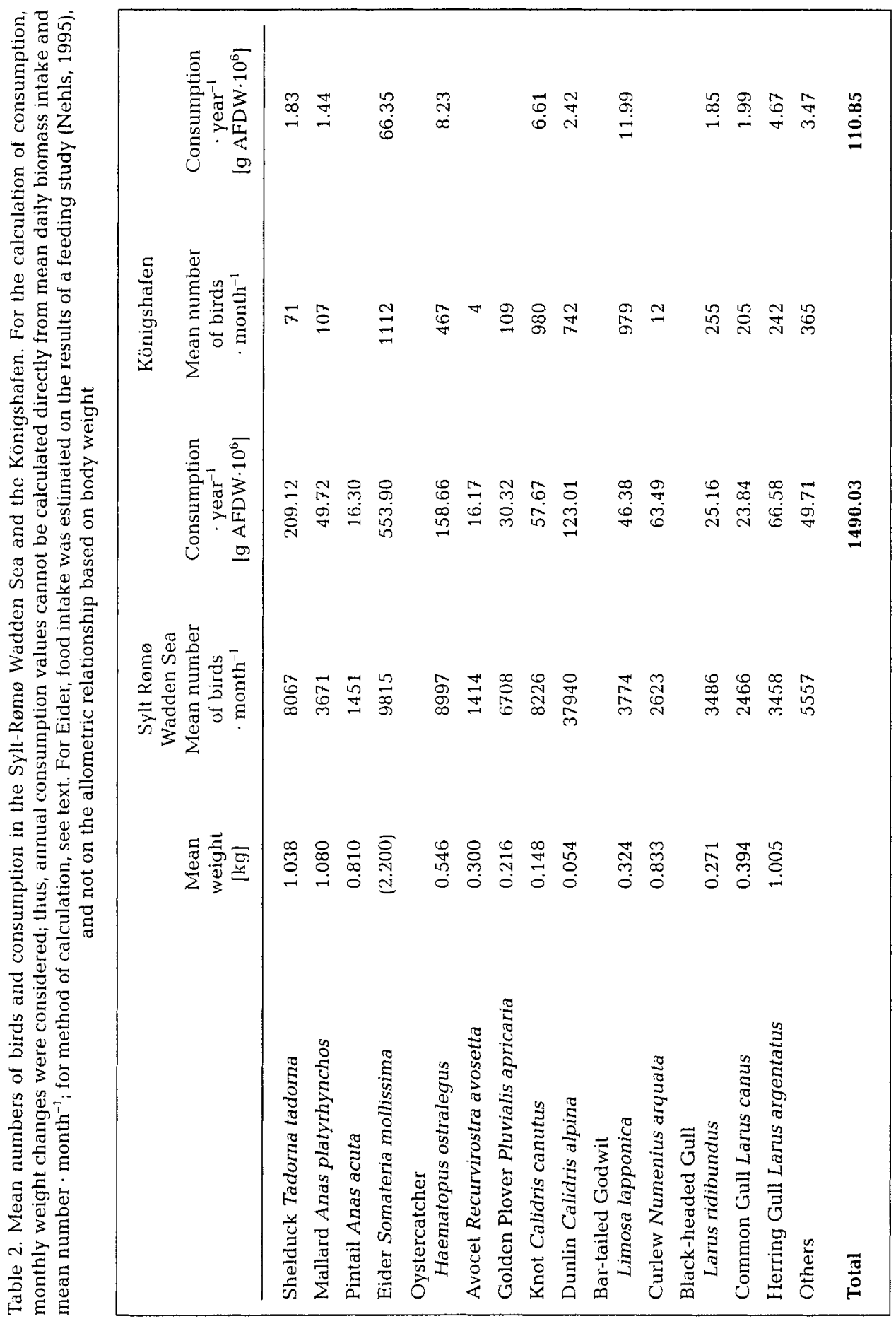



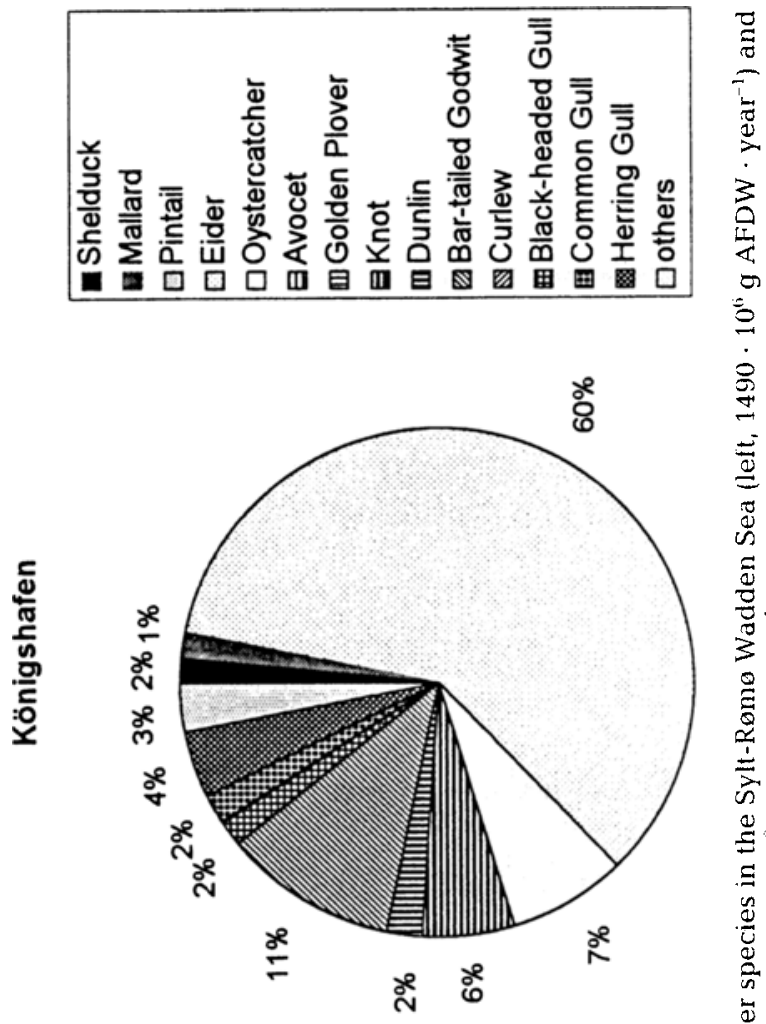

ङ

$\stackrel{\overline{0}}{=}$

芯

홈

政

号点

$\underline{9}$

品

के

$\geqslant$

约

응

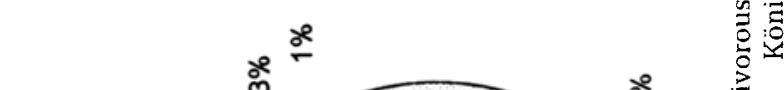

क⿺

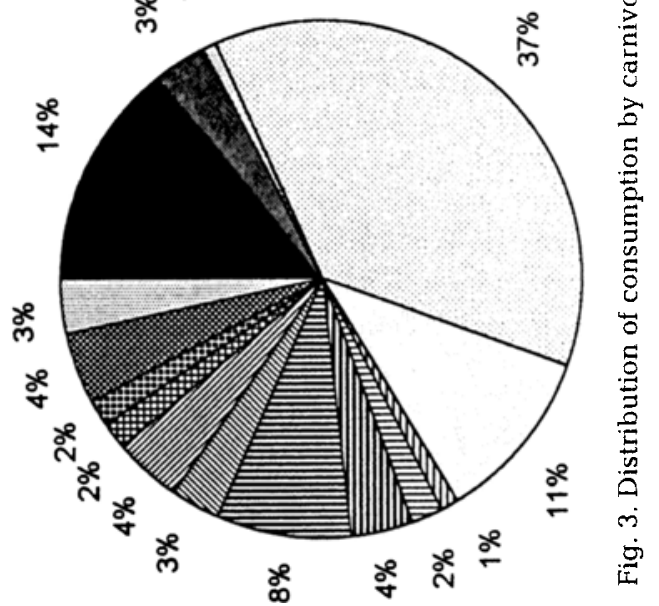


Table 3. Consumption by carnivorous birds in the Sylt-Rømø Wadden Sea, in the Königshafen (both calculated from values given in Tables 1 and 2) and in the Dutch Wadden Sea (Smit, 1980; recalculated with assumptions used in this paper); values are in $\mathrm{g} \mathrm{AFDW} \cdot \mathrm{m}^{-2} \cdot$ year $^{-1}$

\begin{tabular}{|lccc|}
\hline & Sylt-Rømø Wadden Sea & Königshafen & Dutch Wadden Sea \\
\hline Sub- + intertidal area & 3.4 & 19.2 & 3.9 \\
Intertidal area & 8.7 & 17.6 & 6.6 \\
Subtidal area & 0.93 & 23.3 & 1.4 \\
Without Eider & & & 2.5 \\
Sub- + intertidal area & 2.1 & 7.7 & 5 \\
Intertidal area & 6.7 & 10.0 & \\
\hline
\end{tabular}

Sylt-Rømø Wadden Sea

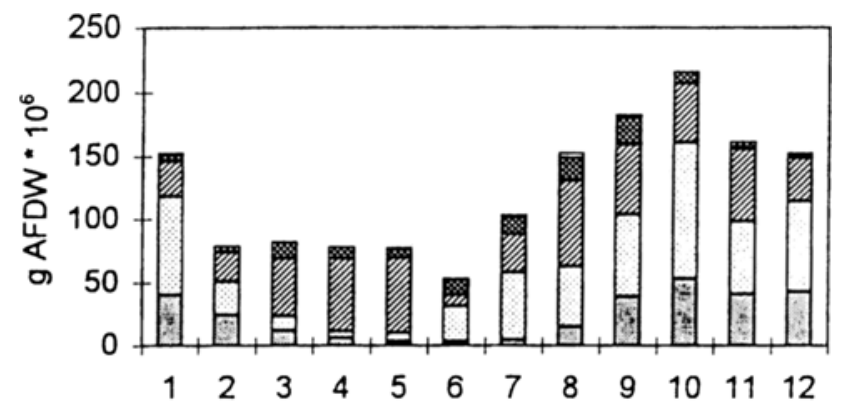

Königshafen

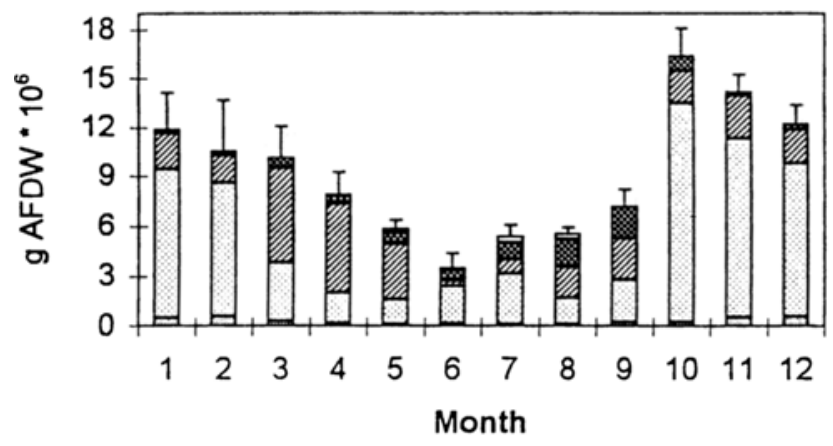

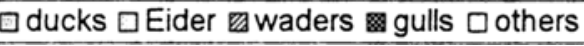

Fig. 4. Seasonal pattern of consumption by carnivorous birds in the Sylt-Rømø Wadden Sea (top) and the Königshafen (bottom, + $1 \mathrm{SE}, 4-6$ years per month) 
low level (Beukema, 1981; Asmus, 1982, 1987). Only waders migrating through the area in May and August/September profit from the seasonal pattern of benthic production.

\section{DISCUSSION}

Comparing the results from the Sylt-Rømø Wadden Sea with the Königshafen, it appears that the size of an intertidal area has a strong impact on consumption by birds, as consumption is $50 \%$ higher in the Königshafen than in the whole Sylt-Rømø Wadden Sea. Even in the light of a higher benthic biomass within the Königshafen, compared to that of the entire Sylt-Rømø Wadden Sea, a higher proportion of biomass is consumed by birds in the Königshafen. Probably, this is an effect of the sheltered bay with a large proportion of sandflats at mean tide level. Furthermore, short distances between high-tide roosts and low-tide foraging areas might be a criterion for habitat selection (cf. Swennen, 1984), since, even within the Königshafen, tidal flats near the high-tide roost were preferred for foraging (Scheiffarth \& Nehls, 1995). In addition, the habit of many waders and gulls of foraging along the moving tideline for most of the year (Evans, 1979; Nehls \& Tiedemann, 1993) enhances bird numbers in small bays with elongated tidelines as compared to a straight coastline (Evans \& Dugan, 1984). In all, it seems almost independent of scale, whether comparing two adjacent areas (this study), a larger region like eastern England (Prater, 1981) or the entire East Atlantic Flyway (Hockey et al., 1992), that smaller intertidal areas face higher bird densities than larger areas.

For a large-scale comparison of consumption within the Wadden Sea, Smit's (1980) estimates for the Dutch Wadden Sea for the seventies were recalculated on the basis of our assumptions. This resulted in an annual consumption of $6.6 \mathrm{~g} \mathrm{AFDW} \cdot \mathrm{m}^{-2} \cdot \mathrm{year}^{-1}$ for the tidal flats of the Dutch Wadden Sea (Table 3), which is $34 \%$ below the value calculated for the tidal flats of the Sylt-Rømø Wadden Sea in the nineties. Whether this difference really exists remains open, since for most species an increase in numbers in all parts of the Wadden Sea has been observed (Meltofte et al., 1994; Rösner, 1994; Smit \& Zegers, 1994). This is most probably due to both improved registration and a real increase in bird numbers. At least for the Dutch Wadden Sea, increasing bird numbers are paralleled by increasing benthic biomass due to eutrophication of the tidal flats (Beukema, 1989), so that the proportion of biomass taken by birds may not have changed. Whether or not there was an increase in benthic zoomass in the northern part of the Wadden Sea during the last 20 years is not yet clear (Jensen, 1992; Reise et al., 1994).

At present the consumption by birds at the northern end of the Wadden Sea should not be lower than at the western end. As species richness and biomass of the macrobenthic communities in the Sylt-Rømø Wadden Sea are similar to those in the Dutch Wadden Sea (Reise et al., 1994; Lackschewitz, 1995), consumption by birds equals 15-25\% of the mean annual zoobenthic biomass in both areas. The equal amount of absolute consumption per $\mathrm{m}^{2}$ as well as predation rate on tidal flats is in contrast to the much lower densities of wintering waders in the northern part of the Wadden Sea than in the Dutch part (Zwarts, 1988). Most of the smaller species leave the northern parts in winter. An equal level of consumption is not only achieved by higher numbers during spring or autumn, since the share of waders in total consumption reaches only $35 \%$ in the Sylt-Rømø Wadden Sea as compared to $44 \%$ in the Dutch Wadden Sea but also by the higher proportion of large and heavy birds, such as Shelduck, in the Sylt-Rømø Wadden 
Sea. Especially in late autumn and winter, Eider and Shelduck dominate the bird community. This can be regarded as a reaction to the harsher conditions in the northern part of the Wadden Sea as compared to the western parts, because large birds have lower thermostatic costs than small birds (Wiersma et al., 1993). Additionally, the phenology of consumption reflects the unfavourable winter conditions for most of the bird species in the northern Wadden Sea. A sharp drop in bird numbers appears from January to February, when the risk of ice-cover is highest. In contrast, consumption in the western Wadden Sea is high throughout winter and reaches a peak in February (Smit, 1980). This may reflect immigration from the northern parts of the Wadden Sea. Although differences in the climatic conditions apparently affect species composition as well as the seasonal patterns of consumption in the two subareas of the Wadden Sea, this has no negative impact on total consumption by birds. Consumption within the Wadden Sea seems to differ only on a local scale related to structural elements in the landscape, e.g. sediment composition, bays, etc.

The proportion of $15-25 \%$ of mean annual biomass taken by birds as calculated in this study falls well within the range of the results from other studies conducted in temperate estuaries on the European continent (for a recent review, see Meire et al., 1994). Only in Great Britain have slightly higher values apparently been achieved (Baird et al., $1985)$. In contrast, a much higher proportion of the mean biomass (82.7\%) as well as production ( $42.6 \%$ ) is consumed by birds on the Banc d'Arguin, Mauritania (Wolff \& Smit, 1990). One major reason for this difference between temperate and tropical estuaries may be stability, with low annual variability and therefore long-term predictability of food resources on tropical mudflats (Wolff, 1991).

Until now the processes linking consumption by birds with production of their invertebrate prey are only marginally understood. Questions concerning whether or not bird numbers are limited by food resources in the Wadden Sea must be investigated on the species level, since different species have a different sensitivity to fluctuating food resources (Beukema et al., 1993).

Acknowledgements. First, we would like to express our greatest gratitude to the numerous people who have been counting birds over the years. The Danish National Environmental Research Institute made unpublished data available. We thank especially John Frikke for the aerial surveys, and Iver Gram and Lars Maltha Rasmussen for the counts from Margrethe Kog. Spring-tide counts on Sylt and in the Rickelsbüller Koog were co-ordinated by Hans-Ulrich Rösner from the WWF, who also made the data available. Furthermore, we would like to thank the Naturschutzgemeinschaft Sylt e.V., Birgit Andresen from the Amt für Land- und Wasserwirtschaft, Husum, and Ralph Tiedemann for co-ordinating and conducting counts in 'their' areas. The manuscript was improved by the comments of Franz Bairlein, Hermann Hötker and an anonymous reviewer. This study was supported by the BMBF and is publication no. 276 of the project 'Ecosystem Research Wadden Sea'.

\section{LITERATURE CITED}

Aschoff, J. \& Pohl, H., 1970. Der Ruheumsatz von Vögeln als Funktion der Tageszeit und der Körpergröße. - J. Orn. 111, 38-47.

Asmus, H., 1982. Field measurements on respiration and secondary production of a benthic community in the northern Wadden Sea. - Neth. J. Sea Res. 16, 403-413.

Asmus, H., 1987. Secondary production of an intertidal mussel bed community related to its storage and turnover compartments. - Mar. Ecol. Prog. Ser. 39, 251-266.

Austen, I., 1994. The surficial sediments of Königshafen - variations over 50 years. - Helgoländer Meeresunters. 48, 163-171. 
Backhaus, J., Hartke, D. \& Hübner, U., 1995. Hydrodynamisches und thermodynamisches Modell des Sylter Wattenmeeres. SWAP Teilprojekt 4.1a. Abschlußbericht. Hamburg, $104 \mathrm{pp}$.

Baird, D. \& Milne, H., 1981. Energy flow in the Ythan estuary, Aberdeenshire, Scotland. - Estuar. coast. Shelf Sci. $13,455-472$.

Baird, D., Evans, P. R., Milne, H. \& Pienkowski, M. W., 1985. Utilization by shorebirds of benthic invertebrate production in intertidal areas. - Oceanogr. mar. Biol. 23, 573-597.

Baird, D., McGlade, J. M. \& Ulanowicz, R. E., 1991. The comparative ecology of six marine ecosystems. - Phil. Trans. R. Soc. Lond. (B) 333, 15-29.

Baird, D. \& Ulanowicz, R. E., 1993. Comparative study on the trophic structure, cycling and ecosystem properties of four tidal estuaries. - Mar. Ecol. Prog. Ser. 99, 221-237.

Banse, K., 1995. Antarctic marine top predators revisited: homeotherms do not leak much $\mathrm{CO}_{2}$ to the air. - Polar Biol. 15, 93-104.

Beukema, J. J., 1981. Quantitative data on the benthos of the Wadden Sea proper. In: Invertebrates of the Wadden Sea. Ed. by N. Dankers, H. Kühl \& W. J. Wolff. Balkema, Rotterdam, 134-142. (Rep. Wadden Sea Working Group. 4.)

Beukema, J. J., 1989. Long-term changes in macrozoobenthic abundance on the tidal flats of the western part of the Dutch Wadden Sea. - Helgoländer Meeresunters. 43, 405-415.

Beukema, J. J., Essink, K., Michaelis, H. \& Zwarts, L., 1993. Year-to-year variability in the biomass of macrobenthic animals on tidal flats of the Wadden Sea: how predictable is this food source for birds? - Neth. J. Sea Res. 31, 319-330.

Castro, G., Myers, J. P. \& Rickleffs, R. E., 1992. Ecology and energetics of Sanderlings migrating to four latitudes. - Ecology 73, 833-844.

Castro, G., Stoyan, N. \& Myers, J. P., 1989. Assimilation efficiency in birds: a function of taxon or food type? - Comp. Biochem. Physiol. 92A, 271-278.

Cramp, S. \& Simmons, K. E. L., 1983. The birds of the Western Palearctic. Oxford Univ. Press, Oxford, 3, 1-913.

Dernedde, T., 1993. Vergleichende Untersuchungen zur Nahrungszusammensetzung von Silbermöwe (Larus argentatus), Sturmmöwe ( $L$. canus) und Lachmöwe (L. ridibundus) im Königshafen/Sylt. - Corax 15, 222-240.

Eisma, D., 1980. Natural forces. In: Geomorphology of the Wadden Sea. Ed. by K. S. Dijkema, H.-E. Reineck \& W. J. Wolff. Balkema, Rotterdam, 20-31. (Rep. Wadden Sea Working Group. 1.)

Evans, P. R., 1979. Adaptations shown by foraging shorebirds to cyclical variations in the activity and availability of their intertidal invertebrate prey. In: Cyclic phenomena in marine plants and animals. Ed. by E. Naylor \& R. G. Hartnoll. Pergamon Press, Oxford, 357-366.

Evans, P. R. \& Dugan, P. J., 1984. Coastal birds: numbers in relation to food resources. In: Coastal waders and wildfowl in winter. Ed. by P. R. Evans, J. D. Goss-Custard \& W. G. Hale. Cambridge Univ. Press, London, 8-28.

Hockey, P. A. R., Navarro, R. A., Kalejta, B. \& Velasquez, C. R., 1992. The riddle of the sands: Why are shorebird densities so high in southern estuaries? - Am. Nat. 140, 961-979.

Humphreys, W. F., 1979. Production and respiration in animal populations. - J. Anim. Ecol. 48, $427-453$.

Jensen, K. T, 1992. Macrozoobenthos on an intertidal mudflat in the Danish Wadden Sea: comparisons of surveys made in the 1930s, 1940s and 1980s. - Helgoländer Meeresunters. 46, 363-376.

Kersten, M. \& Piersma, T., 1987. High levels of energy expenditure in shorebirds; metabolic adaptations to an energetically expensive way of life. - Ardea 75, 175-187.

Krebs, C. J., 1985. Ecology. Harper \& Row, New York, 800 pp.

Kuipers, B. R., de Wilde, P. A. W. \& Creutzberg, F., 1981. Energy flow in a tidal flat ecosystem. - Mar. Ecol. Prog. Ser. 5, 215-221.

Lackschewitz, D., 1995. Besiedlungsmuster des Makrobenthos im Sylt-Römö-Wattenmeer. SWAP Teilprojekt 2.2/2.3/3.2. Abschlußbericht. List, $52 \mathrm{pp}$.

Meire, P. M., Schekkermann, H. \& Meininger, P. L., 1994. Consumption of benthic invertebrates by waterbirds in the Oosterschelde estuary, SW Netherlands. - Hydrobiologia 282/283, 525-546.

Meltofte, H., Blew, J., Frikke, J., Rösner, H.-U. \& Smit, C. J., 1994. Numbers and distribution of waterbirds in the Wadden Sea. Results and evaluation of 36 simultaneous counts in the Dutch-German-Danish Wadden Sea 1980 - 1991. IWRB Publication 34/Wader Study Group Bull. 74 (Spec. issue), 1-192. 
Nehls, G., 1989. Occurrence and food consumption of the Common Eider, Somateria mollissima, in the Wadden Sea of Schleswig-Holstein. - Helgoländer Meeresunters. 43, 385-393.

Nehls, G., 1991. Bestand, Jahresrhythmus und Nahrungsökologie der Eiderente, Somateria mollissima, L. 1758, im Schleswig-Holsteinischen Wattenmeer. - Corax 14, 146-209.

Nehls, G., 1995. Strategien der Ernährung und ihre Bedeutung für Energiehaushalt und Ökologie der Eiderente (Somateria mollissima (L. 1758)). Diss., Univ. Kiel, 173 pp.

Nehls, G. \& Tiedemann, R., 1993. What determines the densities of feeding birds on tidal flats? A case study on Dunlin, Calidris alpina, in the Wadden Sea. - Neth. J. Sea Res. 31, 375-384.

Pihl, S. \& Frikke, J., 1992. Counting birds from aeroplane. In: Manual for aeroplane and ship surveys of waterfowl and seabirds. Ed. by J. Komdeur, J. Bertelsen, \& G. Cracknell. - IWRB Spec. Publ. 19. 8-23.

Prater, A. J., 1981. Estuary birds of Britain and Ireland. Poyser, Calton, $440 \mathrm{pp}$.

Prokosch, P., 1988. Das Schleswig-Holsteinische Wattenmeer als Frühjahrs-Aufenthaltsgebiet arktischer Watvogelpopulationen am Beispiel von Kiebitzregenpfeifer (Pluvialis squatarola, L. 1758), Knutt (Calidris canutus, L. 1758) und Pfuhlschnepfe (Limosa lapponica, L. 1758). - Corax 12, 273-442.

Reise, K., 1985. Tidal flat ecology. Springer, Berlin, $191 \mathrm{pp.}$

Reise, K., Herre, E. \& Sturm, M., 1994. Biomass and abundance of macrofauna in intertidal sediments of Königshafen in the northern Wadden Sea. - Helgoländer Meeresunters. 48, 201-215.

Rösner, H.-U., 1994. Population indices for migratory birds in the Schleswig-Holstein Wadden Sea from 1987 to 1993. - Ophelia (Suppl.) 6, 171-186.

Rösner, H.-U. \& Prokosch, P., 1992. Coastal birds counted in a spring-tide rhythm - a project to determine seasonal and long-term trends of numbers in the Wadden Sea. - Publ. Ser. Neth. Inst. Sea Res. 20,275-279.

Rösner, H.-U., Roomen, M., Südbeck, P. \& Rasmussen, L. M., 1994. Migratory waterbirds in the Wadden Sea 1992/1993. Common Wadden Sea Secretariat \& Trilateral Monitoring and Assessment Group, Wilhelmshaven, 72 pp. (Wadden Sea Ecosystem. 2.)

Scheiffarth, G. \& Nehls, G., 1995. Nutzung unterschiedlicher Wattflächen im Königshafen. In: Trophischer und regulierender Stellenwert der Vögel im Ökosystem Wattenmeer. Ed. by H. Bohlken \& H. Hötker. SWAP Teilprojekt $1.7 \mathrm{a} / 2.5 \mathrm{a} / 4.5 \mathrm{~b}$. Abschlußbericht. Büsum, 104-137.

Smit, C. J., 1980. Production of biomass by invertebrates and consumption by birds in the Dutch Wadden Sea area. In: Birds of the Wadden Sea. Ed. by C. J. Smit \& W. J. Wolff. Balkema, Rotterdam, 290-301. (Rep. Wadden Sea Working Group. 6.)

Smit, C. J. \& Wolff, W. J. (Eds), 1980. Birds of the Wadden Sea. Balkema, Rotterdam, 308 pp. (Rep. Wadden Sea Working Group. 6.)

Smit, C. J. \& Zegers, P. M., 1994. Shorebird counts in the Dutch Wadden Sea, 1980-91: a comparison with the 1965-77 period. - Ophelia (Suppl.) 6, 163-170.

Swennen, C., 1984. Differences in quality of roosting flocks of Oystercatchers. In: Coastal waders and wildfowl in winter. Ed. by P. R. Evans, J. D. Goss-Custard \& W. G. Hale. Cambridge Univ. Press, London, 177-189.

Wiersma, P., Bruinzeel, L. \& Piersma, T., 1993. Energiebesparing bij wadvogels: over de kieren van de Kanoet. - Limosa 66, 41-52.

Wiersma, P. \& Piersma, T., 1994. Effects of microhabitat, flocking, climate and migratory goal on energy expenditure in the annual cycle of Red Knots. - Condor 96, 257-279.

Wolff, W. J., 1991. The interaction of benthic macrofauna and birds in tidal flat estuaries: a comparison of the Banc d'Arguin, Mauritania, and some estuaries in the Netherlands. In: Estuaries and coasts: spatial and temporal intercomparisons. Ed. by M. Elliot \& J.-P. Ducrotoy. Olsen \& Olsen, Fredensborg, 299-306.

Wolff, W. J. \& Smit, C. J., 1990. The Banc d'Arguin, Mauritania, as an environment for coastal birds. - Ardea 78, 17-38.

Zwarts, L., 1988. Numbers and distributions of coastal waders in Guinea-Bissau. - Ardea 76, 42-55.

Zwarts, L. \& Blomert, A.-M., 1990. Selectivity of Whimbrels feeding on Fiddler Crabs explained by component specific digestibilities. - Ardea 78, 193-208.

Zwarts, L. \& Wanink, J. H., 1993. How the food supply harvestable by waders in the Wadden Sea depends on the variation in energy density, body weight, biomass, burying depth and behaviour of tidal-flat invertebrates. - Neth. J. Sea Res. 31, 441-476. 